REVIEWS

\title{
ALMEIDA, S. Racismo estrutural. [Structural Racism] São Paulo: Pólen, 2019. 264 p. ISBN 978-85-98349-75-6.
}

\section{Juliana Harumi Chinatti Yamanaka*}

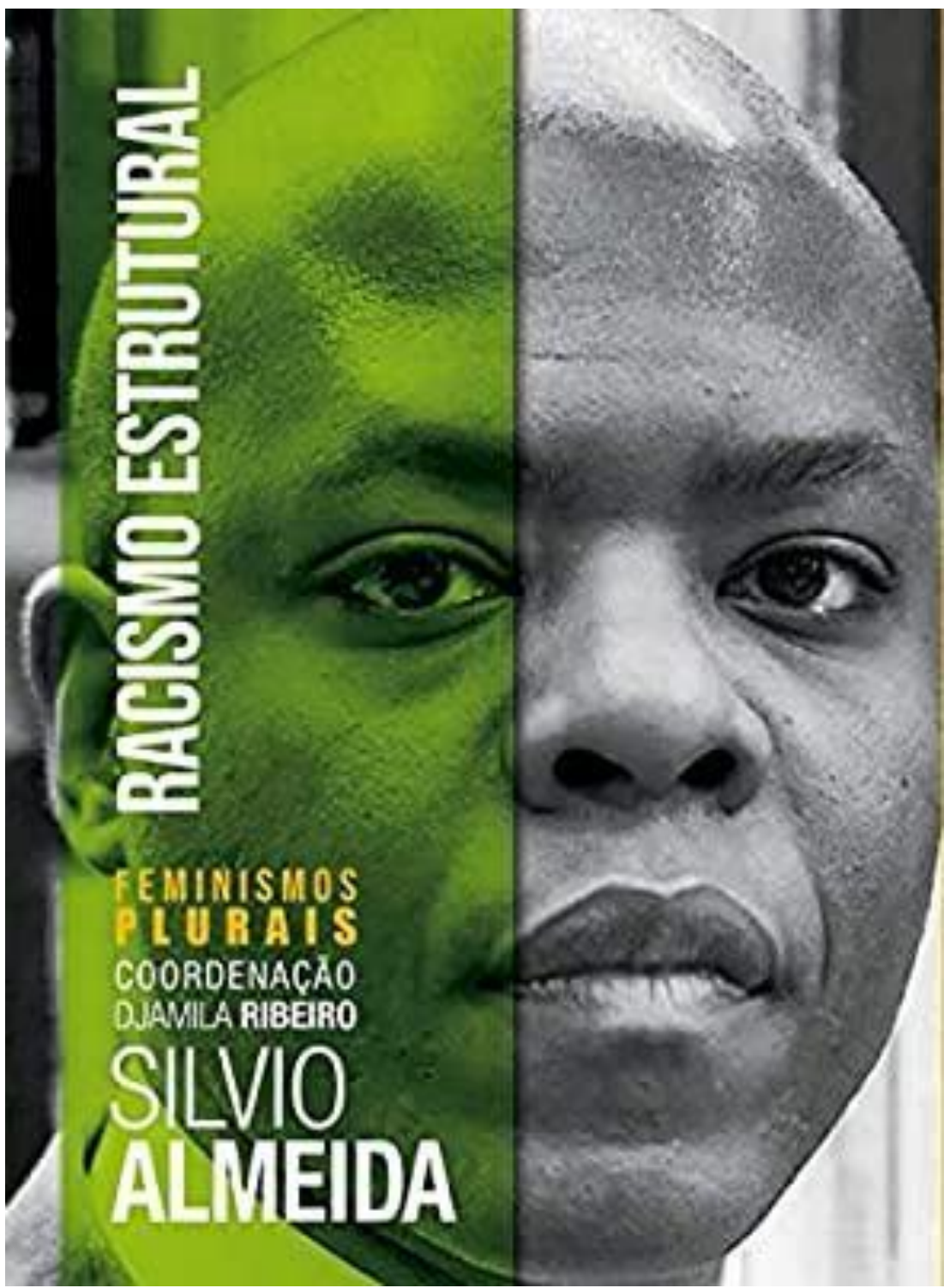

\footnotetext{
* Universidade de Brasília - UnB/FD, Departamento de Linguística, Português e Línguas Clássicas, Doutoranda no Programa de Pós-Graduação em Linguística, Brasília, Federal District, Brazil; http://orcid.org/0000-0001-5783-5939; julianalapsis@ gmail.com
} 
Power and ideology have both been objects of research of the scientific study of language in the past 90 years, but it was particularly as of this century (although not exclusively) that theories began to question the universal man model that would include the racial perspective within the theoretical framework of their research.

Ever since then, the dialogue between discourse analysis research and a social theory that provides elements for understanding the connection between power and linguistic resources could no longer be put off by those seeking to facilitate social criticism and change in Brazil. Against this background, the racial issue emerges as a main topic of discussion among discourse analysis researchers dealing with social interactions in the context of a semi-periphery country, as in the case of Brazil.

Such a social theory is important in that, in addition to the formal elements from which a linguistic analysis based on the internal features of the language may be inferred, the nature of discourse invariably leads to factors which lie outside the linguistic system i.e. to the social dimension of language (VOLOŠINOV, 1973). ${ }^{1}$ Hence, whereas the value of a sign is a social construct, which at times overlaps with ideologies, discourse is a social practice mediated by other multiple practices establishing a relational dialectics with the social structures.

This line of approach is based on regarding discourse as another moment of social practice that should be analyzed alongside other non-semiotic practices of the social process (FAIRCLOUGH; MELO, 2012). Discourse is, therefore, another dimension of the social process worth investigating, not necessarily central to or independent of other social practices of the material world (FAIRCLOUGH, 2003).

In order to better understand the dialectics relation between language and society, a dialogue between Linguistics and Social Science studies is needed. To that purpose and taking the Brazilian context into account, "Racismo Estrutural" [henceforth Structural Racism] by Silvio Almeida is recommended since his distinguishing theoretical research is paramount to have a clear picture of racial issues in Brazil.

Holder of a PhD from the University of Sao Paulo School of Law, Almeida is currently associate professor at the Mackenzie Presbyterian University, Sao Paulo, Brazil, and associate professor at the Getulio Vargas Foundation School of Business

\footnotetext{
${ }^{1}$ VOLOŠINOV, V.N. Marxism and the Philosophy of Language. Translated by Ladislav Matejka and I.R. Titunik. Cambridge, Massachusetts, London, England: Harvard University Press, 1973.
} 
Administration, and has carried out an extensive research on law and philosophy studies. "Republicanismo e questão racial" [Republicanism and the racial issue]; "Crise, racismo e neoliberalismo" [Crisis, racism and neoliberalism]; "Estado e direito: a construção da raça" [State and law: a racial construction] are among the papers produced by Almeida.

Almeida's most recent work, Structural Racism, itself is not focused on discourse analysis, but it is worth reading as it points out issues related to the subjects, the history, and the social contexts of language - elements that should not be neglected when the Brazilian situation is the subject of discourse analysis. Aiming primarily at introducing a critical and in-depth contemporary social theory, whilst maintaining a didactic approach, Structural Racism challenges the reader to think about discourse issues within racist practices networks. To that end, the author provides an overview on philosophy, political science, as well as legal and economic theory in dialogue with the concept of race over the course of the book.

Structural Racism is a 264-page pocketbook that makes up the series Plural Feminisms, ${ }^{2}$ released by Pólen Publishing Company in 2019 under the imprint Sueli Carneiro. The book features the researchers Marcelo Paixão (University of Texas at Austin, USA) and Luiz Felipe de Alencastro (University of Paris-Sorbonne Paris and Getulio Vargas Foundation School of Business Administration) endorsing the importance of Structural Racism in its final cover.

The book is divided into five major chapters - Raça e racismo [Race and racism], Racismo e ideologia [Racism and ideology]; Racismo and política [Racism and politics]; Racismo e direito [Racism and law]; and Racismo e economia [Racism and economics]. In general, each chapter deals with a key issue: "racism is always structural, i.e. [...] it is an element inherent to the economic and political organization of society. [...] it is the normal expression of a society, not a pathological phenomenon or some form of abnormality"3 (ALMEIDA, 2019, p.20).

In the first chapter, "Raça e racism” [Race and racism], Almeida (2019) develops the concept of race, which, while analyzed under a relational and historical approach,

\footnotetext{
2 Other important publications released by the series Plural Feminisms ("Feminismos Plurais," in Portuguese) address racist humor, cultural appropriation, mass incarceration, religious intolerance, intersectionality, and place of speech.

${ }^{3}$ Original: "o racismo é sempre estrutural, ou seja, [...] ele é um elemento que integra a organização econômica e política da sociedade. [...] é a manifestação normal de uma sociedade, e não é um fenômeno patológico ou que expressa algum tipo de anormalidade."
} 
goes back to the 16th century, and has changed since then. However, it was following the Enlightenment Project in the 18th century that there was a rise of a new secular type of racism, so far justified on the grounds of theological beliefs. ${ }^{4}$ Within the Enlightenment project, man becomes the main object of study in philosophy and anthropology, being represented in the dichotomy of civilized versus savage. In the following century, this very same man becomes the object of investigation and pseudoscientific discourses that would, in a deterministic manner, associate biological characteristics, climatic and/or environmental conditions with moral, psychological, and intellectual differences. Such biologically-based theories of race played a role in providing ideological claims to support colonial politics even after slavery had been abolished. This can be seen in the first great crisis of capitalism that had begun in 1873, and which resulted in imperialism and neocolonialism in the African territory.

After a brief outline of the historical background, Almeida describes the similarities and specificities regarding the terms prejudice, discrimination, and racism, while highlights how, throughout history, discrimination has become "social stratification, an intergenerational phenomenon affecting the life course of all members from a social group - including the chances of achieving social mobility, social recognition and means of subsistence" ${ }^{\circ 5}$ (ALMEIDA, 2019, p.33). Subsequently, the author presents three approaches to racism: individualistic, institutional, and structural. The objective is to stress the importance of recognizing racism over and above a problem of deviant, irrational or abnormal behavior of a single individual or a group, but rather as a set of unconscious, conscious, and even institutionalized practices that interact in such a manner that they ultimately normalize "political, economic, legal and even familiar relations"6 (ALMEIDA, 2019, p.52).

The second chapter, "Racismo e ideologia" [Racism and ideology], a must-read for discourse analysis researchers is focused on explaining issues such as (i) naturalization of racism, (ii) the relations among racism, ideology, and social structure, (iii) the role of

\footnotetext{
${ }^{4}$ According to Munanga (2004), other theories used by the Calvinists found mytical support in the tale of Noah and his three sons (who were descendants of white, yellow, and black race) to justify and legitimize antiblack racism.

${ }^{5}$ Original: "estratificação social, um fenômeno intergeracional, em que o percurso de vida de todos os membros de um grupo social - o que inclui as chances de ascensão social, de reconhecimento e de sustento material - é afetado."

${ }^{6}$ Original: "relações políticas, econômicas, jurídicas e até familiares."
} 
science and culture in keeping racism alive, (iv) where white people stand in the process of racialization, and, finally, (v) the relationship between racism and meritocracy.

According to Almeida (2019), perpetuating racism is possible insofar as (i) it creates a system to specifically justify racial inequality, and (ii) it forms subjective insensitivity in face of racial discrimination and violence. In this ideological operation, science and culture play a major role. The first by producing expert-based discourses, pervaded by authority and a matter-of-fact approach that have been perfected throughout the development of capitalism and technological progress as to replace, for example, scientific racism by "cultural relativism" and "multiculturalism," which in turn evoke, in the latter, a model of society that can be controlled, and in which the practice of cultural annihilation is exchanged for the power of determining value and sign. The social theory presented by Almeida enables us to perceive that the possibility to assign value and meaning always takes place on the basis of a relational operation in the simultaneous social construction of whites and blacks differently from another, particularly how they are treated in the law enforcement system and labor regimes. It is therefore absolutely imperative to question meritocracy since it considers that all social subjects are allegedly given equal opportunities in a society ruptured by capitalism.

In the third chapter, "Racismo and política" [Racism and politics], the author (i) defines the concept of State and its relation with capitalism (ii) by explaining the articulation of a nationalist narrative in this context. In addition, this chapter addresses (iii) representativeness, (iv) biopolitics, and (v) necropolitics.

As a complement to the previous chapter, which ends with the approach to meritocracy, Almeida begins the third chapter by laying the grounds of his social theory, which inevitably discusses the Theory of the Bourgeois State. Here, Almeida voices his sharp criticism against the liberal theory which, based on the ideal that individuals are free (in particular to form contracts) in the capitalist system, is limited to an individualistic perspective of racism that perceives the whole set of racial discrimination solely through the lens of a personal deviant behavior in terms of ethics when facing (formal) equality established by law. To show how racism, State, and capitalism relate to each other, Almeida borrows from Mascaro (2013, p.19) the concept that "reproducing capitalism is 
built upon specific and necessary social forms, which are the core of its own sociability,"7 one of these forms being racism.

According to Almeida (2019), it is not possible to understand racism unless we take into consideration how it operates within the state structures, as it is within the state that individuals are subject to being classified and divided. Nationalism, in turn, offers a functional approach in an attempt to rebuild a common identity towards ending conflicts among different groups/classes and the contradictions of capitalism, which over time has improved its strategies and methods to be reproduced across the world. For instance, the author points out the limits of representativeness in predominantly white institutions; the act of educating, ruling or putting an end to lives; and the continuation of a bureaucratic, mortal system, which has self-claimed itself as "of exception," but then again is rather a form of politics aimed at the genocide of black Brazilians.

The fourth chapter, "Racismo e direito" [Racism and law], is divided into six sections, namely (i) law and justice, (ii) law as rule, (iii) law as power, (iv) law as social relation, (v) race and legality, and (vi) law and antiracism.

Along the above-mentioned sections, the author explains contrasting ideas on how law is related not only to historical periods at different points in time, but also to various social justice projects. Part of this discussion levels critics to the individualistic perspective as it disregards the impacts of state institutions on promoting racism or raising suspicion on concepts based on a merely ethical point of view, i.e. that still remains focused on the individual by ignoring how complex structural racism is in different dimensions (ideological, cultural, political, economic, institutional, and material). Against this line of thinking, the author proposes to consider the legal practice in the light of dynamics of power and social relations within capitalism. A particular point of attention is the excellent approach made by the author to resume the social theory in linking law, the emergence of capitalist societies and the conception of "racist practices based on legality"8 (ALMEIDA, 2019, p.136), which supports colonial conditions in the contemporary world. This section, in particular, provides key theoretical contributions for discourse analysis researchers, as well for the theoretical, political, and ethical debate.

\footnotetext{
${ }^{7}$ Original: "a reprodução do capitalismo se estrutura por meio de formas sociais necessárias e específicas, que constituem o núcleo de sua própria sociabilidade."

${ }^{8}$ Original: "a reprodução do capitalismo se estrutura por meio de formas sociais necessárias e específicas, que constituem o núcleo de sua própria sociabilidade."
} 
The fifth and last chapter addresses "Racismo e economia" [Racism and economics], a crucial issue to understand the structured perspective in the social theory devised by Almeida. The author's efforts to explore the issue can be observed in the 14 subsections dedicated to deal with the relationship between racism and economics. These sections resume all preliminary ideas developed in the first chapter, as well as throughout the book, which already led to its main topic of debate: "How is racism, as an enduring legacy of the colonial exploitation, projected into the current Brazilian situation by means of structuring (and being structured by) the set of institutions and relations within the peripheral capitalism, allowing its perpetuation in that system?"

In summary, Almeida's book overcomes any limitations which the pocketbook format might impose to the comprehension of the discussion proposed. As for its contribution to discourse analysis studies, we recommend reading and understanding the book as a whole, rather than focusing solely on the chapter dedicated to ideology.

Almeida's approach to structural racism proves to be a powerful instrument for the comprehension of discourse analysis that takes into account the epistemological perspective of the subjects directly affected by this social phenomenon, which has language as one of its support tools.

\section{REFERENCE}

ALMEIDA, S. L. Republicanismo e questão racial. In: SCHWARCZ, L. M.; STARLING, H. M. (org.). Dicionário da república: 51 textos críticos. São Paulo: Companhia das Letras, 2019.

ALMEIDA, S. L.; VELLOZO, J. C. O. Crise, racismo e neoliberalismo. In: SOUZA, E. A.; OLIVEIRA e SILVA, M. L. (org.). Trabalho, questão social e serviço social: a autofagia do capital. 1. ed. São Paulo: Cortez Editora, 2019.

ALMEIDA, S. L. Estado e direito: a construção da raça. In: SILVA, M. L.; FARIAS, M.; OCARIZ, M. C.; STIEL NETO, A. (org.). Estado e direito: a construção da raça. São Paulo: Escuta, 2018, v. 1, p.81-96.

FAIRCLOUGH, N. Analysing Discourse: Textual Analysis for Social Research. London: Routledge, 2003.

FAIRCLOUGH, N.; MELO, I. Análise Crítica do Discurso como método em pesquisa social científica. Linha D’Água, v. 25, n. 2, p.307-329, 10 dez. 2012. https://www.revistas.usp.br/linhadagua/article/view/47728. Acesso em 19/06/2021.

MASCARO, A. L. Estado e forma política. São Paulo: Boitempo, 2013, p.19-21.

MUNANGA, K. Uma abordagem conceitual das noções de raça, racismo, identidade e etnia. In: Programa de educação sobre o negro na sociedade brasileira [S.1: s.n.], 2004. 
VOLÓCHINOV, V. (Círculo de Bakhtin). Marxismo e filosofia da linguagem: problemas fundamentais do método sociológico na ciência da linguagem. 1. ed. Tradução de

Sheila Grillo e Ekaterina Vólkova Américo. São Paulo: Editora 34, 2017 [1929].

Translated by Janaina de Aquino - janainadeaquino@gmail.com

Received July 21,2020

Accepted May 17,2021 